\title{
Requirements specification for mobile software for e-commerce and its adoption by small organic farmers in Costa Rica
}

Jose Francisco Aguilar ${ }^{1}$

\begin{tabular}{l}
\hline I N F O \\
Received \\
Accepted \\
Available on-line \\
Responsible Editor: \\
Keywords: \\
ICT adoption, e-commerce, \\
rural development, digital \\
divide, mobile software.
\end{tabular}

\begin{abstract}
A B S T R A C T
Rural development can be favoured not only with the development of new and sustainable agricultural practices, but also with information communication technology applications. Requirements analysis and specification for mobile software has been recognized as a key factor for economic success and as a support to E-commerce. With the aim to develop a mobile application for a small group of farmers, a partnership among the Ministry of Agriculture and Livestock (MAG), the Institute Costa Rican Electricity, Telecommunications (ICE), the University of Costa Rica (UCR), and a group of organic farmers was established. Here we describe the different processes and the connection between the user needs and the software development team. After defining the specific roles of each organization, we provided especial consideration for the adoption phase, due to digital divide of the target group of small organic farmers. The analysis conducted concluded that the creation of the mobile application had both benefits and challenges. On one hand, it represented an important first step into the world of Information Communication Technology (ICT) applied to organic farming activities in Costa Rica that can surely boost e-commerce. The needs were potentially solved by the inherent advantages of ICT in an increasingly competitive world, with equity of opportunities, and the important challenge to preserve the biodiversity with sustainable agricultural practices. The specifications of mobile software requirements established in this project were supported by considerations of adoption and of collaboration, cooperation and communication strategies among key stakeholders to follow-up, the implementation phase and to assure success.
\end{abstract}

\section{Introduction}

The World Conference on Computers in Agriculture (WCCA), held in San Jose Costa Rica in 2014, provided a forum where professionals from different disciplines exchanged research findings and experiences on the use of Information Communication Technology (ICT) in a wide variety of contexts. This paper was originated after this WCCA meeting, with the aim to develop apps for mobile devices, in order to provide an e-commerce service to small organic farmers, and in this way, to allow them to be more competitive through improved information and communication processes. The development of mobile applications is having both an enormous global impact in e-commerce networks, as well as in information services. Besides, there is an urgent need to consider the adoption of methods of software engineering, that reduce the intrinsic complexity in specific features of the environment (eds Alencar \& Cowan 2012, p.413). The required analysis and specifications for mobile software have been recognized as key factors for success.

The Government of Costa Rica, well aware of the benefits of organic practices in agriculture, has recently created a Department of Organic Agriculture within the Ministry of Agriculture and Livestock (MAG). A recent study requested by MAG showed the need to foster these practices by assisting farmers in their products commercialization; particularly, farmers will benefit with current higher earnings if they sell directly to consumers. MAOCO (Costa Rican Organic Agriculture Movement) is a not-profit

\footnotetext{
${ }^{1}$ José Francisco Aguilar

Escuela de Ingeniería Agrícola

Facultad de Ingeniería

Universidad de Costa Rica

jose.aguilar@ucr.ac.cr
} 
organization that is working closely with farmers, promoting the offer and demand of organic products in local spaces like "farmer markets". MAOCO is a lead social movement that seeks to promote and develop the production of organic products by integrating producers, consumers, and other actors, while focusing on the respect to life, biodiversity, and indigenous knowledge; among their objectives are to promote a common vision to change politics, society, and economics, in order to improve rural livelihoods. MAOCO, has a central office in San Jose and other 11 regional branches to give support to different rural groups.

ICE (the government's telecoms arm), MAG, MAOCO and the University of Costa Rica started a collaboration and are working together in order to develop a mobile app to assist small organic farmers to sell their products via "the web". This way, the app will provide consumers with information in order to locate particular dealers where they can buy the desired products. This paper describes the detail of software development, considering a close partnership between the user needs and the development team, and keeping all the considerations for the adoption, due to digital divide for the target group of small organic farmers.

\section{Materials and methods}

\subsection{Project background and organic agriculture in Costa Rica}

With the objective to define a reference framework of the organic agriculture activity in Costa Rica, (managed by the Ministry of Agriculture and Livestock (MAG)), official information and documents regarding the action plans for the promotion of organic agriculture, within the State Policy for the Agrifood Sector and Rural Development in Costa Rica, were reviewed from 2010 to 2021. Besides, the information contained in the organic agriculture activity census conducted in 2013, constituted a valuable document that comprised a national and international study that showed its evolution in the last 15 years and its current status. On the other hand, the implementation of the Law 8591 (CR. MAG 2013) and information of the agricultural census conducted in 2014 (CR. INEC 2015) were additionally considered.

With this information available, the current and potential actors within the organic farming development were detected. This way, for this project and this contribution, a synergy between MAG, MAOCO, ICE and UCR was established; these actors were characterized and their roles as participants in the project were defined. Additionally, the current marketing procedures of organic farmers were analysed and characterized through questionnaires.

\subsection{Analysis of cell phone coverage and limitation of ICT for digital commerce}

The evaluation of cell phone coverage provided by ICE was performed according to the report of the Superintendence of Telecommunications (Sutel) of Costa Rica. The analysis evaluated the quality of service to locate the members of MAOCO organic producers group, as well as the conventional farmers markets and organic farmers markets.

Besides, the reports prepared by the Institutional Program of Information Society and Knowledge of the University of Costa Rica for 2014 (Universidad de Costa Rica, PROSIC 2015) and 2012 (Universidad de Costa Rica, PROSIC 2013), showed the importance and increase of ICT use in production processes and social networks in marketing. Finally, an analysis of ICT access in rural and urban areas was conducted, focusing on householders engaged in agricultural activities, with the aim to evaluate the limitations in the use of ICT and digital divide.

\subsection{Software requirements specification and prototype}

As a first step, a survey was designed to analyse the needs and requirements of farmers in ICT for electronic commerce. Then, a digital commerce strategy was established with mobile applications and the development priorities were established, that considered the adoption factors. For this purpose, ICE, MAG, MAOCO and UCR, established the terms of reference, and indicated their roles, contributions and responsibilities. 
Besides, recommendations for the specifications of the software requirements of IEEE 830-1998 were used for mobile applications, such as detailing use cases, navigation and others. Finally, a prototype was designed, which included the specifications and the functional and non-functional features, to support quality assurance and validation consultation processes.

\section{Results}

\subsection{Project background in organic agriculture in Costa Rica}

The national organic production export-oriented proportion is of $69 \%$, and the national consumption is $31 \%$. Exporting producers indicated that the national market does not pay the right price, so they look for ways to market their products in countries that pay a fair and competitive price. Products that do not meet the minimum requirements of abroad markets are selling within the country at a lower price. Producers indicated the need to develop actions aimed at encouraging the marketing of organic products nationwide, due to the lack/limitations of market (CR. MAG 2013). In this sense, policies and actions should promote domestic consumption, favouring both producers and consumers, and allowing the local market to offer export quality products.

In a study of local organic agriculture in Costa Rica (CR. MAG 2013), different sectors such public, private, academic, support and union were featured as linked to organic agriculture, or that can potentially participate as actors. Currently, there are 48 actors working on at least one topic related to organic agriculture, and other 20 actors having the structure and conditions to implement activities to strengthen organic agriculture. According to current and potential actors related to organic agriculture, there has been a synergy between MAG and MAOCO, which are considered as current actors, and ICE and UCR, which are featured as potential actors, who will participate and were committed to this project.

\subsubsection{Characterization of the project participants}

MAOCO is a social movement that promotes and develops organic farming. It recognizes peasant, indigenous and technical knowledge. It has 15 years of experience with representatives throughout the country through partnerships and farmer markets. This organization worked for seven years for the creation of the Law on Promotion of Organic Agriculture, which is now in MAG for approval.

The interviews conducted highlighted that organic producers in the country do not have the resources for advertising campaigns, through which they may make their products locally known. A mobile application for organic products would provide the producers with the ability to make themselves known throughout the country as well as to collect data that enable them to determine a specific product demand, allowing them to produce according to a specific place and time to sell their products. Besides, this application would potentially allow prices regulation across the country.

MAG's mission is to promote the dignity of rural families of small and medium producers, promoting the development of technical skills and business management in production systems and in agricultural organizations, to promote competitiveness, equity and social, economic and environmental sustainability of farming. This ministry ensures the development of producers and their families. Recently, there is an initiative in process to create a new department focused on organic farmers.

In the country, to be certified as biologically or ecologically organic by the state or a third agency, according to the law and its regulations, a product must be certified, but many producers do not have these certifications because of the high cost and time it takes to process. In this sense, the MAG seeks to facilitate producers if they are coordinated as a group of farmers and could take less time if they can show that in the last 10 years there has been no toxics or chemicals used.

ICE is a public corporation that provides electricity and telecommunications solutions, contributing to the economic, social and environmental development. This project is framed within the topics of interest of ICE, within its social responsibility program, where the communities and farmers' associations, community associations, and associations are working for an integral development. 
UCR is a public higher education institution, dedicated to teaching, research and extension. The University seeks in this project to promote the integration of alliances with social commitment to promote innovation, and transfer the knowledge generated in this project.

\subsubsection{Characterization of marketing procedures made by farmers}

There are six points within the country in which organic producers place their products for marketing. Figure 1 shows the proportions using these marketing channels by domestic producers.

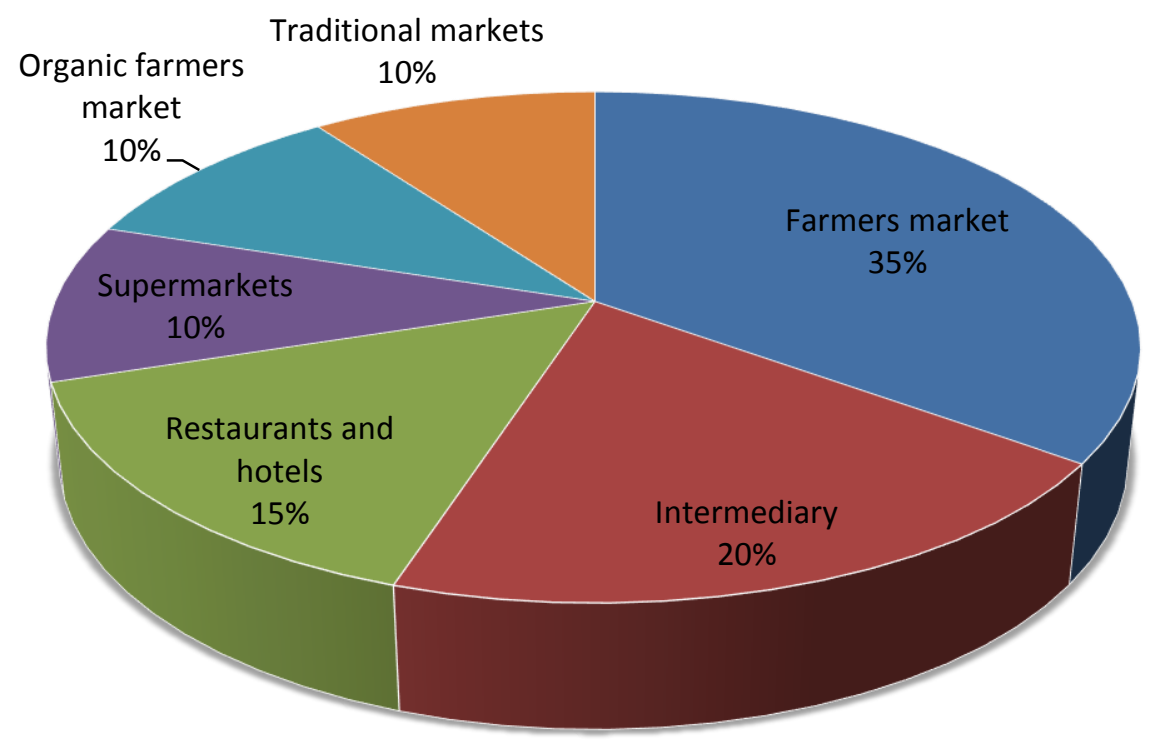

Figure 1. Marketing channels for organic producers in Costa Rica (CR. MAG 2013)

The $35 \%$ of producers sell their products in farmers markets; according to the 2013 census they must compete with the prices of non-organic products (despite their certifications), since many domestic customers are unwilling to pay more. These marketing channels have several difficulties such as the lack of support for the promotion and dissemination $(38 \%)$, little product and variety $(21 \%)$, lack of price control policy (22\%) and deficient producers location information (19\%) (CR. MAG 2013). This project is highly relevant because it greatly solves the promotion and dissemination, where consumers can learn more about the benefits of these organic products, and at the same time, get the location of the organic farmers markets. The mobile application can access a database with product information in addition to its location, facilitating greater producer trust to help them place larger quantities of products.

\subsection{Analysis of mobile phone coverage and accessibility situation of ICT for digital trade in small organic farmers}

\subsubsection{Coverage and quality of cellular signal in producing areas}

The coverage and quality of the service provided by ICE (ICE 2015) were analysed in areas defined by MAOCO which include organic farmers' members, associations and organic farmer's market locations. The results obtained are shown in Figure 2.

In $68 \%$ of the places evaluated, ICE had an excellent or very good coverage, which is a positive sign for the project. Farmers will have access to cell phone and internet services, this way they will able to use of the application. 


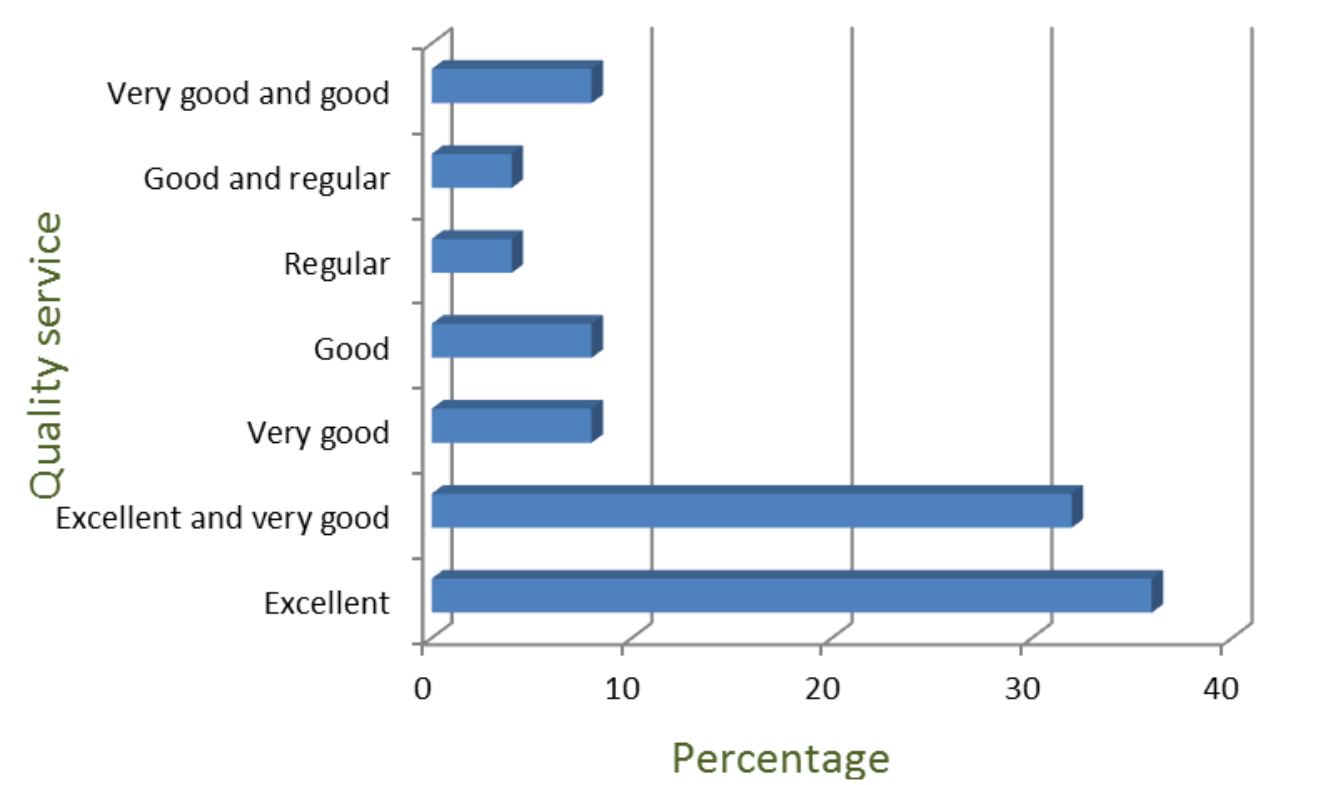

Figure 2. Cellular coverage and quality service in organic producer's locations

\subsubsection{Access to technology by Costa Rican society and agricultural producers}

The incorporation of ICT in production processes can generate large benefits for people who depend on the competitiveness of local businesses. However, a lot of them still base their production processes in obsolete methods in a contemporary society, having great difficulty in meeting the demands of information requirements, customer service and product quality (Universidad de Costa Rica, PROSIC 2015). It has been found that the use of social networks as a mean of advertising and communicating have been heavily exploited, and has been one of the tools most commonly used by small and medium enterprises. In general, most companies (66\%) use social networks as marketing means, and $47 \%$ for sales (Universidad de Costa Rica, PROSIC 2013, Universidad de Costa Rica, PROSIC 2012). Mobile applications are to constitute the centre of the broadband ecosystem which facilitates the interaction between farmers and consumers, and the potential of social networks which bring together the same organic farmers.

In terms of the evolution of ICT access in Costa Rican households from 2010 to 2013, it was found that by 2013 (92\%) of Costa Rican households had at least one cell phone; in addition, Internet service have had the highest growth rate of all technologies, since it almost doubled between $2010(24 \%)$ and 2013 (47\%) (Universidad de Costa Rica, PROSIC 2013). Analysing this by rural and urban areas, both areas have electricity, colour television and cell phone (holding percentage higher than $90 \%$ households in both areas). However, the difference between these areas in computer and Internet access is negative.

In urban areas, both the percentage of households with a computer and Internet access is $20 \%$ higher than in rural areas. Residents in rural areas must leave their homes to get access to a computer or Internet connection. In rural areas, the transfer is much more complicated and much more distances; thus, many of these people have not a real choice to access these technologies that are key to their development (Universidad de Costa Rica, PROSIC 2015). In rural areas, the majority of households with Internet access are connected through mobile devices (59\%), followed by cable modem (17\%) and high-speed system ICE (10\%). This is a positive finding, since the idea of using a telephone application, even though it may not have access to the entire rural population, the Internet access via mobile phone is high.

With the information gathered it was not possible to assume that all the inhabitants of rural areas were engaged in agriculture, due to the development and land use that occurs in Costa Rica. A series of analysis were proceeded to have a combination of results concerning internet access, computers and cell phone in Costa Rican homes focused on householders. The householders dedicated to agriculture and qualified agricultural, forestry and fishery workers is shown in Table 1. 
Table 1. Heads of household farmers and qualified agricultural, forestry and fishing workers

\begin{tabular}{lrr}
\hline \multicolumn{1}{c}{ Service } & $\begin{array}{c}\text { Number of } \\
\text { households }\end{array}$ & Percentage \\
\hline Rural area with desktop & 6,791 & $16.6 \%$ \\
Rural area with laptop & 5,085 & $12.4 \%$ \\
Rural area with cell phone & 31,399 & $77.0 \%$ \\
Rural area with internet & 4,569 & $12.6 \%$ \\
Urban area with desktop & 4,690 & $31.7 \%$ \\
Urban area with laptop & 3,461 & $23.4 \%$ \\
Urban area with cell phone & 12,965 & $88.0 \%$ \\
Urban area with internet & 4,265 & $28.8 \%$ \\
\hline
\end{tabular}

\subsection{Software requirements specification and prototype}

\subsubsection{Analysis of the needs and requirements of farmers}

The surveys submitted electronically to farmers had poor response, however, the best gathering was through telephone calls. It is imperative to highlight the importance, for the processes of ICT adoption by small organic farmers, that governmental institutions such as the Ministry of Education (MEP) and the Ministry of Science, Technology and Telecommunications (MICITT), be part of the strategy, in order to promote the inclusion of young people in agriculture and ICT. This is more relevant if we consider that in the agricultural census of 2014, the producer average age was 53.9 years, with 54.1 for men and 52.6 for women, where there is a marked aging of the population, especially if one considers that $22.5 \%$ are 65 years and older (INEC 2015).

Many organic farmers commercialize their products in traditional markets with other farmers having to sell at similar prices. On the other hand, Figure 3 shows the percentages according to the type of operation performed by the organic farmer.

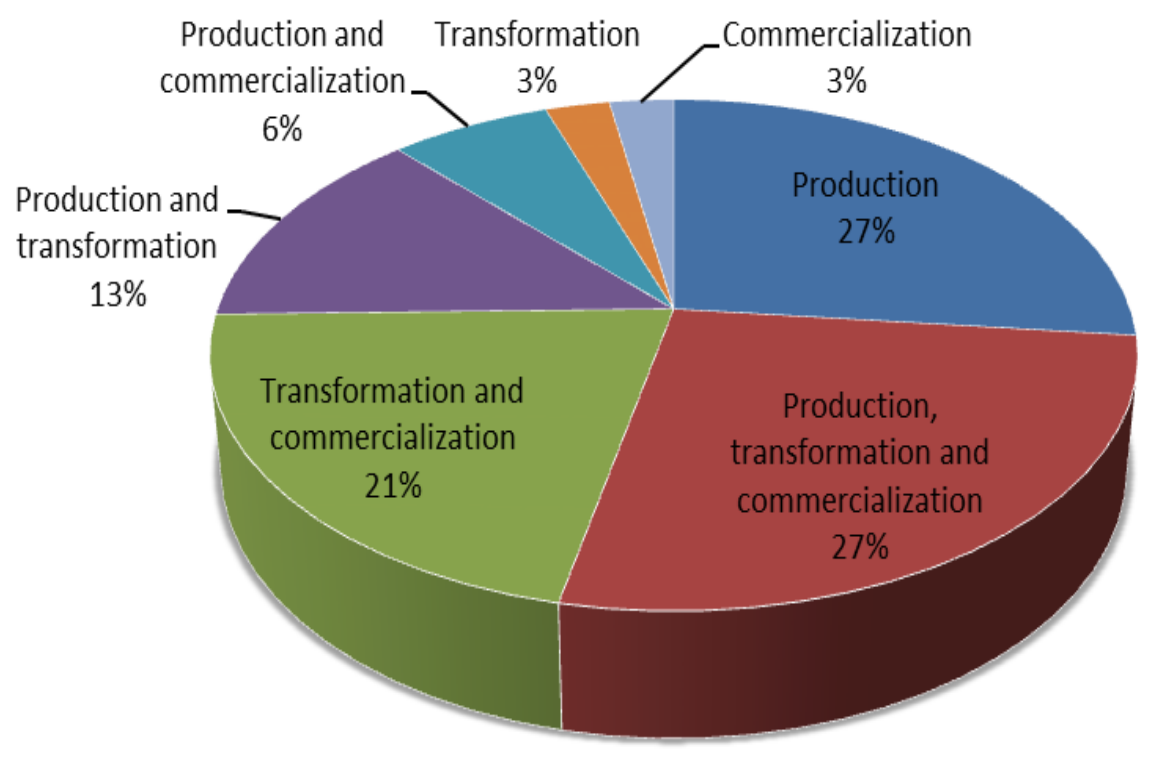

Figure 3. Type of operation for organic farmers in Costa Rica (CR. MAG 2013)

Figure 3 shows that $83 \%$ of organic farmers are producing an organic product, but only $27 \%$ make the whole process (that is production, transforming and commercialization); meanwhile, it is observed that $3 \%$ are dedicated only to commercialization, and only 3\% to transformation; this highlights the 
opportunities they have for adding value to their products, especially for those producers who are only engaged in production, currently represented by $27 \%$ (CR. MAG 2013).

\subsubsection{Requirements specification and prototype mobile application}

Based on the context of small organic farmers need and considerations for adoption in the use of ICT, two mobile applications were strategically defined. Besides, a developmental sequence for its implementation and commissioning was established in order to monitor the evolution of adoption and to start promoting its use, facilitating the scaling to ensure the capacity building among farmers. Both applications were specified with IEEE 830, which provides guidelines for proper specification of software requirements, describing the application purpose, functional requirements (Table 2) and nonfunctional requirements (Table 3), use cases were established for each module and extended use cases.

The first application provides consumers with organic products information supplied by farmers. The development of this application is part of the E-Commerce, which according to the International Organization for Standardization (ISO) is an exchange of information and requirements from businesses or between businesses and their customers (Qin et al. 2014). This definition characterizes very precisely this application, because the aim is an exchange of information between farmers, organic farmers markets and organic associations and potential customers. It is noteworthy that this application do not include electronic payment, a valuable feature in terms of competitiveness; however, this feature will be implemented later, based on the response from the use and ICT adoption.

A strategy of collaboration, cooperation and communication was established between MAOCO, MAG, ICE and UCR for the development of these applications and their implementation, for which each actor had its role and responsibilities. MAOCO will assume the management of information on the reliability and validity of the same, independent producers, organic farmers markets, associations, and additional information (geographic location, general information related to organic production, in addition to certification entities). MAOCO will coordinate with ICE to keep updated information ensuring reliability. It will address the comments of users of the mobile application, on issues related to organic production and marketing. Additionally, MAOCO will disseminate the initiative on its website and through other partnerships. Finally, it will collaborate with the training of independent producers who wish to take advantage of mobile application. MAG, specifically the National Organic Agriculture Program PNAO, shall manage the information about the reliability and validity, and certify independent producers and transition producers, and the general information related to organic production and entities certification. It will coordinate with ICE to keep updated information and ensure reliability. It will address the comments of users of the mobile application, on issues related to organic production, policy and regulation. MAG PNAO will disseminate the initiative on its corporate website and by regional committees, which may be called the productive, academic and public sectors, and where actions are structured to promote research and dissemination of results to producers. MAG PNAO will collaborate with the training of independent producers. ICE has a robust platform with technical ICT, it shall manage the information sent by MAOCO and MAG PNAO, it will be responsible for updating the information users see in the mobile application ensuring the operation of the application; ICE will be on charge for two years, until the MAG has the capacity to do so. ICE will address matters related to the support and maintenance of the mobile application and website. It also will disseminate the initiative in institutional web pages. Lastly, it will be responsible for training in the use of the mobile application to MAG officials. MAOCO will update the information and training of farmers' users. UCR will support the monitoring and adoption of ICT. A technical advisory committee and self-evaluation to be aware of the lines of work will be established assuring the continuity and sustainability of the project. The University disseminates the project by radio, television and weekly newspaper, and by the institutional website of the University. It promotes projects such as university community work where students of Engineering, Agricultural Economics and Social Work may support in training to independent producers, with the aim of encouraging adoption of accomplishing that this application be used in the best way for producers and clients and remain in time. 
Table 2. Main functional requirements for farmer and Consumer mobile application

\begin{tabular}{|c|c|}
\hline \multicolumn{2}{|c|}{ Main functional requirements } \\
\hline Farmer mobile application & Consumer mobile application \\
\hline $\begin{array}{l}\text { 1. The system must run applications for those } \\
\text { modules that do not require internet } \\
\text { connection and should be synchronized once } \\
\text { the connection return. } \\
\text { 2. The system must allow connections to social } \\
\text { networks. } \\
\text { 3. The system must allow to connect to mobile } \\
\text { applications or web pages such as weather, } \\
\text { official produce prices, farm supplies, etc. } \\
\text { 4. After the user is authenticated by MAG, the } \\
\text { system must be able to enter, modify and } \\
\text { delete the user and farm data. } \\
\text { 5. The system must be able to download } \\
\text { documents of all types to provide, to enter, } \\
\text { modify and delete information related to } \\
\text { system costs. } \\
\text { 6. Once accredited by MAG, the system must } \\
\text { be able to enter, modify and delete } \\
\text { information from the user and organic crops. } \\
\text { 7. The system must able to send and receive } \\
\text { user messages, which should be recorded and } \\
\text { stored. }\end{array}$ & $\begin{array}{l}\text { 1. The system must be able to indicate the } \\
\text { current geographical location of the user and } \\
\text { to get the farmer address through the } \\
\text { connection of a navigation application. } \\
\text { 2. The system must be allow to evaluate } \\
\text { independent producers, farmer fairs and trade } \\
\text { associations with a grade from } 1 \text { to } 10 \text {, and } \\
\text { left comments. } \\
\text { 3. The system must have a main menu with the } \\
\text { following modules: Organic Commerce } \\
\text { (Overview and benefits), FAQs and } \\
\text { suggestions, points of sale in a map } \\
\text { categorized as independent farmer, green } \\
\text { fairs and trade associations. } \\
\text { 4. The system must have a search engine for } \\
\text { product, point of sale, and proximity. The } \\
\text { results of the query should have different } \\
\text { levels of detail. } \\
\text { 5. The system must be able to send and receive } \\
\text { user messages, which should be recorded and } \\
\text { stored. }\end{array}$ \\
\hline
\end{tabular}

Table 3. Main non-functional requirements for farmer and Consumer mobile application

\begin{tabular}{l} 
Major non-functional requirements \\
\hline 1. Reliability: the application functions must be discontinue as minimum as possible due to faults \\
in the cell or network. In case of problems with the network, the restart time for the application \\
should be the minimum. \\
2. Usability: it must be user friendly. This is very important because the average age of the farmer \\
target group is 54 years. \\
3. Efficiency: The application must have fast responses without delay to the user, for example, the \\
response time in the navigation in between the modules should be the minimum. Must be taken \\
noted that the cell used by farmers could be not so modern affecting the processing capacity. \\
4. Maintainability: This is associated with the changes suffered by the application, it must adapt to \\
the updates to be made to both the application and the phone software. \\
5. Portability: the application has to run on all types of cell.
\end{tabular}

The prototype of this first application was proposed by ICE (Figure 4) and it has the following functions, reporting organic trade in Costa Rica, guide in finding places to buy organic products, link to producers, associations and farmers market, with the customer. 

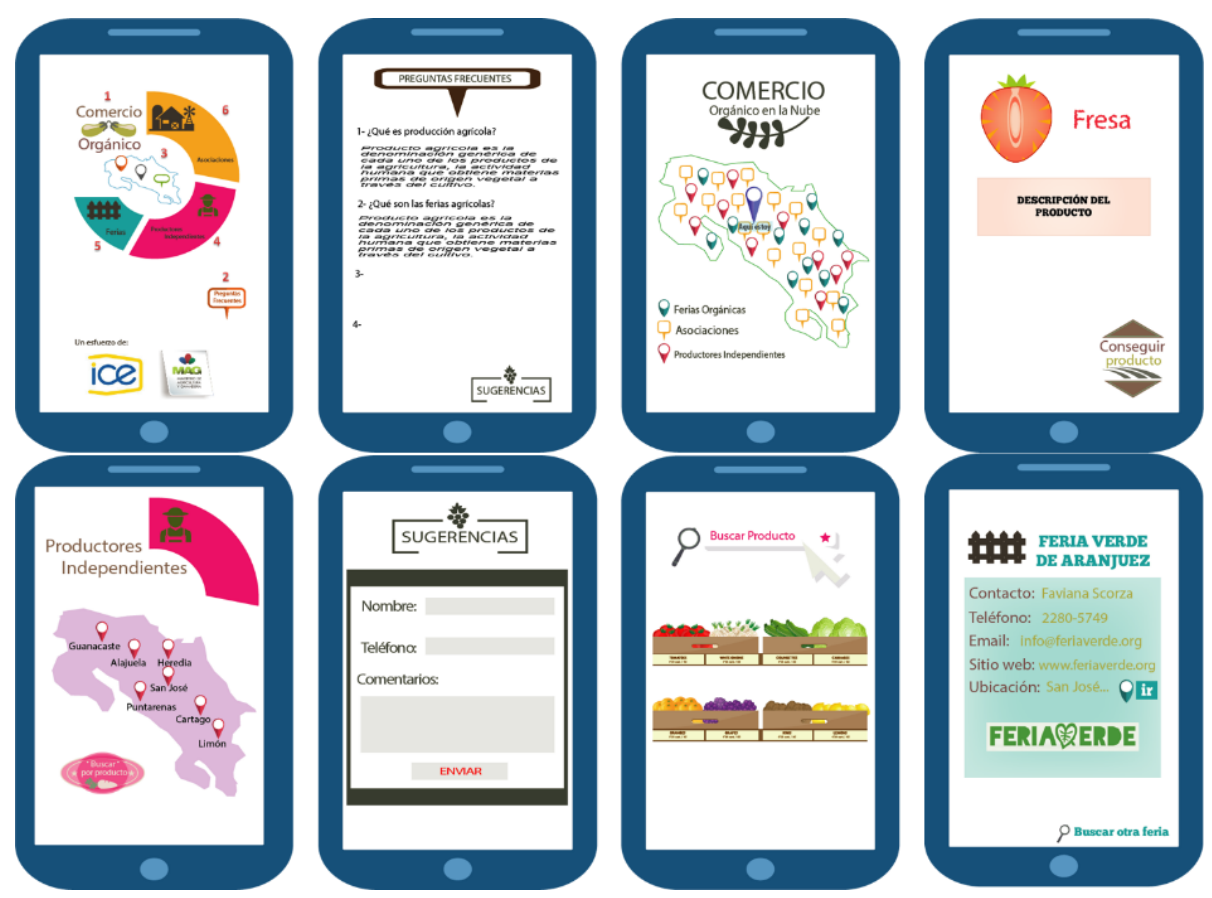

Figure 4. Prototype proposed by ICE

The second application is aimed at fostering social network of organic farmers involved in the National Program for Organic Agriculture of MAG. Once registered, users can access templates related to certification processes, templates to keep track of the farm, finance templates, trends of products prices, offer and demand trends for products, news and events related to organic production, weather information, discussion forums on various topics where the user can create your own topics, FAQs, tips and contacts module.

\section{Conclusions}

From the analysis conducted, it can be concluded that the creation of the organic farmers' mobile application in Costa Rica has benefits and challenges. It is an important first step into the world of ICT applied to organic farming to boost e-commerce. The needs are potentially solved by the inherent advantages of ICT in an increasingly competitive world where access to information will force the pace of the economic world, where equity of opportunities is undoubtedly a challenge. The specifications of mobile software requirements established in this project are supported by considerations of adoption and strategies of collaboration, cooperation and communication among key stakeholders for follow-up, implementation and success Acknowledgements

Raúl Sequeira, Josue Vargas y Rodrigo Cordero de la División de Innovación y Estrategia del Negocio, Instituto Costarricense de Electricidad y Telecomunicaciones (ICE).

María Fernanda Reyes, Coordinadora del Programa Nacional de Agricultura Orgánica Costa Rica, Ministerio de Agricultura y Ganadería (MAG).

Miguel Castro y Xinia Chaves miembros del Movimiento de Agricultura Orgánica Costarricense (MAOCO).

Didier Hernández, Fabio Herrera y Mario Chacón, Instituto Nacional de Estadística y Censo de Costa Rica (INEC).

Luke Reese, Agriculture and Biosystem Engineering Department, Michigan State University (MSU).

Karina Vargas and Guillermo Aguilar students from Escuela de Ingeniería Industrial, Universidad de Costa Rica (UCR).

\section{References}


Alencar, P \& Cowan, D (eds) 2012, 'Handbook of research on mobile software engineering: design, implementation, and emergent applications' Hershey, PA: Engineering Science Reference, USA, pp. 413-426. doi: $10.4018 / 978-1-61520-655-1$

Costa Rica, Ministerio de Agricultura y Ganadería MAG 2013, 'Estudio sobre el entorno nacional de la agricultura orgánica en Costa Rica'. MAG, San José. C.R.

Costa Rica, Instituto Nacional de Estadística y Censos INEC 2015, 'VI Censo Nacional Agropecuario: Resultados Generales'. Instituto Nacional de Estadística y Censos. -- 1 ed. --San José. C.R.

Instituto Costarricence de Electricidad (ICE) 2015, Mapa de cobertura. Available from:

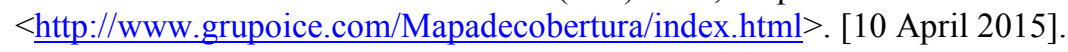

IEEE Recommended Practice for Software Requirements Specifications," IEEE Std 830-1998, vol., no., pp.1, 40, Oct. 20 1998. doi: 10.1109/IEEESTD.1998.88286

Muñoz, D \& Nicaragua, R 2014, 'Un acercamiento a la brecha digital en Costa Rica desde el punto de vista del acceso, la conectividad y la alfabetización digital’ e-Ciencias de la Información, vol.4, no. 1, 1-29. doi: $\underline{10.15517 / \text { eci.v4i1.12866 }}$

Universidad de Costa Rica, Programa de la Sociedad de la Información y el Conocimiento PROSIC 2015, 'Hacia la Sociedad de la Información y el Conocimiento: informe 2014'. Universidad de Costa Rica, San José. Costa Rica

Universidad de Costa Rica, Programa de la Sociedad de la Información y el Conocimiento PROSIC 2013, 'Hacia la Sociedad de la Información y el Conocimiento: informe 2012'. Universidad de Costa Rica, San José. Costa Rica

Universidad de Costa Rica, Programa de la Sociedad de la Información y el Conocimiento PROSIC 2012, 'Hacia la Sociedad de la Información y el Conocimiento: informe 2011'. Universidad de Costa Rica, San José. Costa Rica

Qin, Z, Chang Y, Li S, \& Li F 2014.'E-Commerce Strategy'. Springer Springer Heidelberg New York Dordrecht London, doi: 10.1007/978-3-642-39414-0_1 